\title{
Comparative Sequence Analysis of Keratin Associated Protein (KAP 7.1) Gene in Two Indigenous Pashmina Goat Breeds of India
}

\author{
Aadil Ayaz ${ }^{1,2}$, N. Singh ${ }^{1}$ and Nazir Ahmad Ganai ${ }^{2 *}$ \\ ${ }^{1}$ Department of Zoology and Biotechnology, Hemvati Nandan Bahuguna Garhwal \\ University Srinagar, Uttrakhand-246174, India \\ ${ }^{2}$ Division of Animal Genetics and Breeding, Faculty of Veterinary Sciences and Animal \\ Husbandry Sher-e-Kashmir University of Agriculture Sciences and Technology Shuhama \\ Alusteng Kashmir 190006, India \\ *Corresponding author
}

\begin{tabular}{|l|l|}
\hline \multicolumn{1}{c}{ A B S T R A C T } \\
\cline { 2 - 3 } \multicolumn{1}{l|}{$\begin{array}{l}\text { Keywords } \\
\text { Pashmina, } \\
\text { Changthangi, } \\
\text { Chegu, KAP's }\end{array}$} & $\begin{array}{l}\text { Keratin-associated proteins are fibrillar proteins and are the vital } \\
\text { components of hair and wool fibres as they are part of matrix of fibres and } \\
\text { form a cross- linked network with the keratin intermediate filaments. } \\
\text { Variation in sequence and expression pattern of KAP may affect fibre } \\
\text { characteristics. In this study, we used direct DNA sequencing to analyse the } \\
\text { goat HGT-KAP 7.1gene which codes for the protein responsible for the }\end{array}$ \\
\hline $\begin{array}{l}\text { Accepted: } \\
\text { 30 July 2017 } \\
\text { Available Online: } \\
\text { 10 September 2017 }\end{array}$ & $\begin{array}{l}\text { KAP 7.1 gene sequence of chegu goat. This study would lead to screening } \\
\text { of this single nucleotide variation in larger goat population for any possible } \\
\text { association with fibre fineness, yield or processing properties }\end{array}$ \\
\hline \hline
\end{tabular}

\section{Introduction}

The main structural proteins of hair fibre are keratin-associated proteins (KAPs). In association with keratin protein their content in fibre determines its quality (Jin et al., 2011). KAPs play a vital role in structural and mechanical properties of wool fibre (Liu et al., 2014). Keratin proteins are encoded by two multi gene families type I (acidic) and type II (basic), so the keratin content and structure are more stable in the different species hair, but KAPs differs enormously as they are encoded by large multigene families, which are to be categorized into high sulphur KAP, ultra-high sulphur KAP and high glycine- tyrosine KAPs (Langbein et al.,2001; Rogers et al., 2002; Yin J et al., 2004. The glycine/tyrosine-rich KAPs, are smallest of the hair keratins $(\mathrm{Mr}=6,000-9,000)$ and were originally separated into two groups on the basis of amino acid content and solubility (Powell and Rogers, 1997), type I (KAP7 and 8), and type II (KAP6 family). These proteins are rich in glycine, tyrosine, serine, and phenylalanine, accounting for $\sim 50 \mathrm{~mol} \%$ of 
the amino acid content for KAP7 andKAP8 and $\sim 77 \mathrm{~mol} \%$ for KAP 6 proteins. KAP7 is glycine/tyrosine-rich type I component C2. The glycine/tyrosine-rich KAP group is heterogeneous. Keratin composition of hair significantly determines the quality of hair fibre, and also subject to genetic factors. Due to different expression pattern of KAP genes, the fibre characteristics significantly change in cashmere goat of the different regions and different species (Jeffery et al., 2001). Therefore, from the molecular level keratin and KAP genes are the important factors for controlling fibre fineness and improving cashmere quality.

Cashmere goat generates cashmere and wool. The hair and wool of almost all animal species is mainly composed of cuticle, cortex and medulla. However cashmere commonly known as Pashmina fibre is mainly composed of cuticle and cortex with long polyhedral spindle shaped internal cortical cells (Jones, 2001), which attribute mechanical strength to the fibre. The external covering of the fibre is formed by the flattened overlapping cuticular cells (Marshal etal.,1990). Basically it is the secondary hair follicle which generates cashmere fibre. Histological observation of this dynamic mini organs reveals that it be divided into the outer epidermis, outer and inner root sheath, hair cuticle and cortical layer from outside to inside, while medullary layer only exists in the primary follicles (Rogers GE, 2004).The expression of keratin and their associated protein genes is prerequisite for the formation of cashmere fibre. The continuous upward movement of upper hair matrix cells from their germinal zone gives rise to mature hair shaft as the gene coding for the two structural protein families in the hair matrix, cuticular Layer and cortical layers were activated (Rogers MA, 2002). The high glycine-tyrosine (HGT) KAPs encoded by KAP6n, KAP7 and KAP8 gene families are the smallest of wool keratin.
Variation in the nucleotide sequence and differential expression of these genes regulates the fibre quality in different species. The objective of this study was to identify the variation in KAP 7.1gene in two pashmina producing goat breeds 'Changthangi and Chegu' which would form the basis of a deeper study associating them with performance levels for better fibre quality of the breed. Changthangi also known as Pashmina goat is found in the Ladakh division of Jammu and Kashmir and Chegu is found in Spiti valleys of Himachal Pradesh, Chamoli, Bathwari, Ticknor, Uttarkashi, Pithoragarh, sectors of Uttrakhand (Gupta et al., 2006).

\section{Materials and Methods}

\section{Animals, sample collection and DNA isolation}

Changthangi goats were selected randomly from Changthang regions of Leh Ladakh division of Jammu and Kashmir and Chegu goats were selected from Chamoli, Uttarkashi, Bathwari and Ticknor, Pithoragarh sectors of Uttrakhand for blood sampling. In this study, blood samples $(5 \mathrm{ml}$ each) were collected from jugular vein puncture, using vacuum tubes treated with $0.25 \%$ EDTA and transported to laboratory at $4^{\circ} \mathrm{C}$.Genomic DNA was isolated by phenol-chloroform extraction method (Sambrook and Russel, 2001) with slight modification and checked for quality and the quantity and was diluted to a final concentration of 250/ng and store at $4^{\circ} \mathrm{C}$ further analysis.

\section{DNA amplification by Polymerase Chain Reaction (PCR)}

PCR was carried out on about 50-100 ng genomic DNA in a reaction volume of $25 \mu \mathrm{l}$. 40ng each of diluted primers (Forward 5'TCCTTCTTGGGTAACTTGCTC-3' Reverse R 5'-GCCCTCAATTCTCTGTGT) were used 
to amplify a $365 \mathrm{bp}$ PCR product of the KAP 7.1 gene. The reaction mixture consisted of $200 \mu \mathrm{M}$ dNTP, 1 unit of Taq DNA polymerase, $1.5 \mathrm{mM} \mathrm{MgCl} 2,1.5 \mathrm{mM} 10 \mathrm{X}$ buffer, using Eppendorf PCR machine. Following a hot start $\left(95^{\circ} \mathrm{C}\right.$ for $\left.10 \mathrm{~min}\right), 35$ cycles were carried out $\left(95^{\circ} \mathrm{C}\right.$ for $30 \mathrm{~s}, 54^{\circ} \mathrm{C}$ for $45 \mathrm{~s}, 72{ }^{\circ} \mathrm{C}$ for $45 \mathrm{~s}$ ), ending with a $10 \mathrm{~min}$ final extension at $72^{\circ} \mathrm{C}$.

\section{PCR clean-up and DNA Sequencing}

The PCR product was visualized by electrophoresis through $1.8 \%(\mathrm{w} / \mathrm{v})$ agarose gel by staining with ethidium bromide. The PCR products were purified by PCR purification kit (Thermo). Duplicate samples were chosen for KAP 7.1 gene. Amplified PCR products were subjected to custom DNA sequencing from both ends (5' and 3' ends) (). The PCR products were sequenced by Xcelris Labs India. Nucleotide sequence alignments, translations and comparisons were carried out using the Seaview software 2017. The BLAST algorithm of NCBI (National Center for Biotechnology Information) was used to search the NCBI GenBank (http://www.ncbi.nlm.hih.gov/) databases for homologous sequences. The phylogenetic tree was developed from the nucleotide sequences of KAP 7.1 gene, based on neighbour-joining method using SEAVIEW-4 software 2017.

\section{Results and Discussion}

Cashmere goat breed is a genus of world most earliest domesticated animal species called goat (Capra hircus) and has developed special regulating mechanisms in adapting to the harsh environment of Northern Himalayan ranges, Changthangi and Chegu breeds are mainly reared for meat and fibre purpose. The breeders are completely dependent on these awesome creatures. It is widely accepted that the keratin associated protein 7.1 gene (KAP7.1) belongs to the high glycine-tyrosine group and is the main structural gene. Looking towards the importance of KAP gene, direct DNA sequencing was done to identify the variation(s) if any in KAP7.1 gene in Changthangi and chegu which may be further helpful in genetic improvement in these goat breed. Therefore, we considered it to be very important to screen KAP7.1 gene for such kind of variations. Genetic variability in KAP7.1gene was assessed by direct DNA sequencing. A single transversion $\mathrm{C} \rightarrow \mathrm{A}$ at 95th position of chegu goat sequence was identified, when compared with KAP7.1 gene in Changthangi goat and with reference sequence (AY510121.1) of Capra hircus keratin associated protein 7.1 available at NCBI GenBank database (Table-1).

Table.1 Single nucleotide variation identified in KAP 7.1 gene Chegu and Changthangi goat

\begin{tabular}{|c|c|c|c|c|}
\hline Position & Capra hircus & $\begin{array}{c}\text { Changthangi } \\
\text { Goat }\end{array}$ & Chegu Goat & Type of Change \\
\hline 95 & $\mathrm{C}$ & $\mathrm{C}$ & $\mathrm{A}$ & Transversion \\
\hline
\end{tabular}


Fig.1 Amplified PCR product (365bp) of KAP7.1 gene

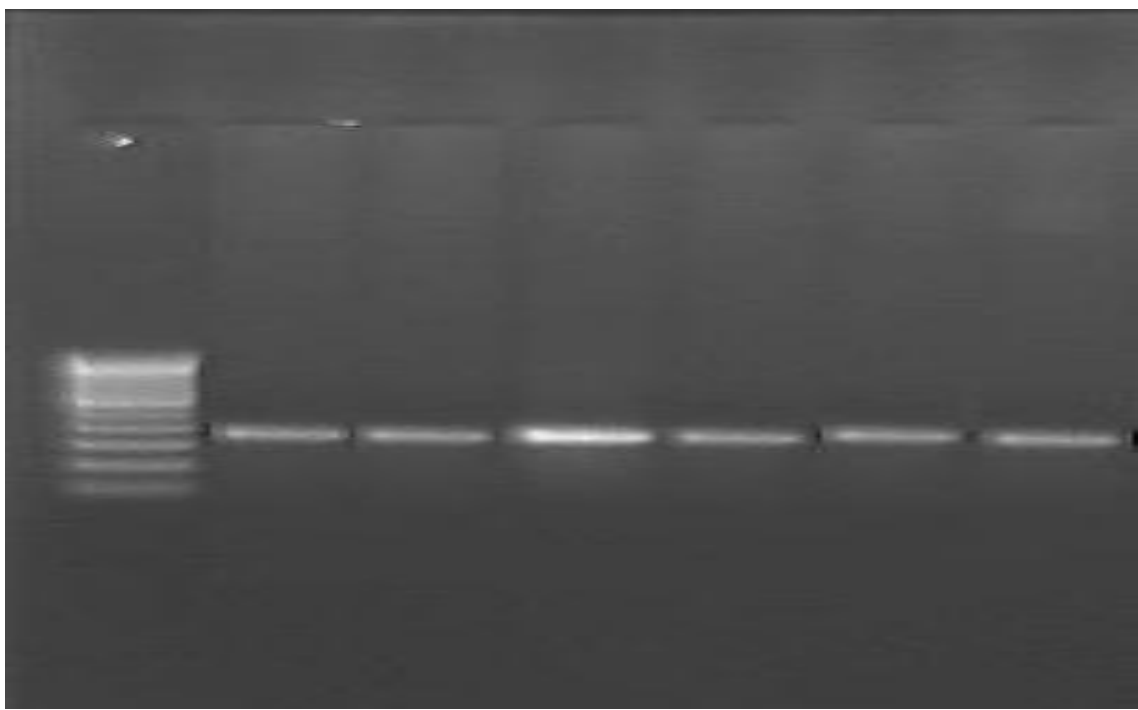

Fig.2 Neighbour- joining tree obtained from KAP 7.1 gene sequence data of different species

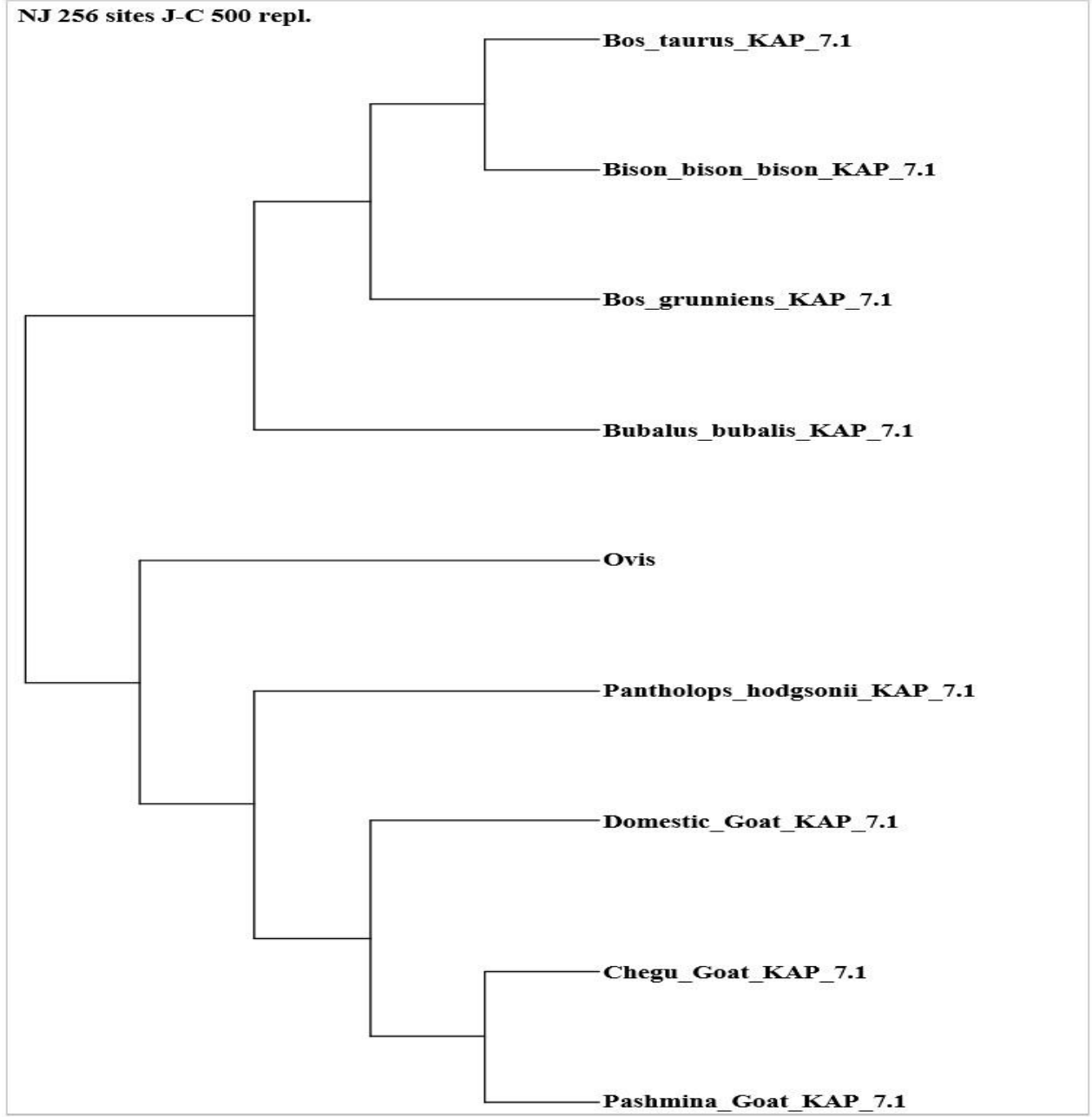


BLAST analysis of KAP7.1 gene of chegu pashmina goat revealed homology of $100 \%$ with Changthangi pashmina goat an domestic goat (Capra hircus), 99\% with Ovis Aries and Panthlops,95\% with Bos taurus and Bos grunniens, 94\% with Bison bison, Phylogenetic analysis of KAP7.1 gene following Neighbour- joining algorithm revealed that Chegu, Changthangi and domestic goat were found in same group, small ruminants were found in one cluster and Bos taurus and Bos grunniens, Bison bison, Bubalus bubalis were found in distinct cluster (Fig. 2).

In conclusion, the significance of this Sequential variation in keratin associated protein (KAP7.1) in any of the Indian goat breeds has not been reported and it would be meaningful if found to be related with some production traits in these breeds. Further validation of the identified variation needs to be done..

\section{Acknowledgement}

This work was financially supported by the Department of Zoology and Biotechnology, HNBGU Srinagar Uttrakhand and Division of Animal Genetics and Breeding F.V.Sc \& AH SKUAST-Kashmir Shuhama Alusteng J\&K. Authors are grateful to Dr. Uniyal, Veterinary Surgeon, Department of Animal Husbandry Uttrakhand Govt., for his support in sampling.

\section{References}

Gupta, N.P., A.K. Pokharana and P.C. Patni, 2006. Prospects of production, processing and marketing of sheep and goat fibres workshop-cum- seminar on commercial goat and sheep farming and marketing Central institute for research on goats. Mathura (India), pp: 79-86

Jeffrey, E.P., Warren GB 2000. Application of proteomics for determining protein markers for wool quality traits. Electrophoresis 21:1899-1906 doi: $10.1002 /$ (SICI) 15222683(20000501)21:9\1899:AIDELP S1899 [3.0.CO; R

Jin, M., Wang, L., Li, S., Xing, M.X. and Zhang, X. 2010. Characterization and expression analysis of KAP 7.1 and 8.2 gene in Liaoning new-breeding Cashmere goat hair follicle. Molecular Biology Reports 38(5): 3023-3028.

Langbein, L., Rogers MA, Winter H et al., 2001. The catalog of human hair keratins. J BiolChem 276:35123-35132

Powell, B.C., 1997. Molecular genetics. In: The Genetics of Sheep, edited by Piper L and Ruvinsky A. Oxon, UK: CAB International. pp 149-181.

Rogers, G.E., 2004. Hair follicle differentiation and regulation. International Journal of Developmental Biology 48:163170.

Rogers, M. A., L. Langbein, H. Winter, C. Eemann, S. Praetzel and J. Schweizer. 2002. Characterization of a first domain of human high glycine-tyrosine and high sulfur keratin-associated protein (KAP) genes on chromosome 21q22.1. J. Biol. Chem. 277:48993-49002.

Sambrook and Rusell, 2001. Molecular cloning. A Laboratory Manual. $3^{\text {rd }}$ edition. Vol 1.Von Bergen, W. 1963 Wool Handbook, Vol I. $3^{\text {rd }}$ Ed., Inter Science Publishers, London. 352-359

Yin, J., Hu TM, Li JQ 2004. Cloning and analysis of six full- length cDNA similar to sheep KAP6-1 from Cashmere goat. Acta Genet Sin 31:502-507.

\section{How to cite this article:}

Aadil Ayaz, N. Singh and Nazir Ahmad Ganai.2017. Comparative Sequence Analysis of Keratin Associated Protein (KAP 7.1) Gene in Two Indigenous Pashmina Goat Breeds of India. Int.J.Curr.Microbiol.App.Sci. 6(9): 3314-3318. doi: https://doi.org/10.20546/ijcmas.2017.609.409 